\title{
The overview of nuclear energy situation in the World and Turkey
}

\author{
Yusuf Alper Kaplan ${ }^{*}$, Merve Karagöz, Serhat Sayılmaz \\ Osmaniye Korkut Ata University, Energy System Department, Turkey
}

\begin{abstract}
The dependence on the energy and its use has increased in every country due to the increasing population and advanced technology. As a result of it, the reserves of fossil fuel have decreased, several energy crises have occurred from time to time and the alternative energy sources have been on the focus. One of these alternative energy sources is nuclear energy. The nuclear power plants, which were built in order to get nuclear energy, have attracted the attention thanks to some disadvantages such as its high cost and emission of radiation while they do not radiate harmful gases towards environment. The nuclear power plants that have already been and are planned to be constructed by a number of countries have become problematic because of the power plant accidents. On one hand, some countries have abandoned the nuclear power plants owing to the accidents mentioned above, on the other hand some other countries have continued to operate the nuclear power plants by claiming the necessity to meet the increasing demand on energy. It is seen that conflicts and problems experienced in the geography in which Turkey is located impacts the energy security of Turkey and it is understood that this situation may have a negative influence on national security of Turkey. Because of all these reasons, actualizing nuclear energy projects are important for Turkey which is dependent in respect of energy.
\end{abstract}

\section{Introduction}

Being addicted to gasoline and gas makes the world research energy strategies. Because of the energy crisis countries aim to evaluate energy gender and conflict energy sector, use alternative energy source [1]. In the current context of globalization, the energy used by a country is not anymore, a suitable indicator for measuring the total energy requirements associated with its level of development; the significant variable is the energy consumed worldwide to produce the goods and services demanded by that country, i.e. its energy footprint [2].

Countries started to find nuclear energy solutions due to energy issues [1]. Nuclear energy is a tool which most of the countries can use to get outmaneuvering against of each other. The main reason of this is that nuclear energy has a potential to affect development of countries by providing economic and fiscal returns [3]. Asian countries, EU countries and USA checking new nuclear stations. National development and industries based on energy and new energy sources (nuclear energy) is also important beside traditional and local energy sources in countries national plans and programs [1]. Nuclear energy is very important since it provides about $17 \%$ of the electric energy in the world and is used in industry and medical area [4].

Turkey has started discussion about nuclear energy in 1960's. There were some cancelation of processes and negations but arguments are starting again nowadays. Supporting and non-supporting groups are telling their opposing views for Turkey's nuclear energy strategies [1].

\section{Nuclear Energy İn The World}

The EU Acquis on nuclear energy; The emphasis was on securing safety in nuclear power generation, disabling plants, managing radioactive waste, assessing environmental impact, and addressing technical aspects [5]. The EU has issued directives on the safety of nuclear installations, with particular emphasis on ensuring nuclear safety. As the amount of world energy is at a certain level, developed countries have emphasized the efficient use of energy for a sufficient use of energy. For this reason, developed countries are studying energy efficiency in detail, and they carry out their R \& D work with care [6]. In particular, it is important to understand how to generate more power from new generation nuclear power plants, to increase the service life of power plants, Is manifested in studies directed towards. EU countries are working on the same amount of energy to make more research and development work for less waste, greenhouse gas and carbon dioxide emissions with less energy, more warming, less energy-consuming technology systems [7].

There are 449 nuclear reactors in 31 countries shown in Fig. 1. Also, there are 60 power plant is under construction shown in Fig. 2 [3]. USA obtains electricity from $\% 20$ nuclear energy and world's most nuclear central country with 99 centrals. This ratio is $\% 77$ in France; \%19 in Russia with 35 centrals (8 central are

* Corresponding author: yakaplan@osmaniye.edu.tr 
under construction); \%30 in South Korea with 24 centrals (4 central are under construction). China has started 23 nuclear central construction which has 31 central already. There are a lot of nuclear centrals in oil and gas-rich countries even. Such as; USA, Canada, England, Russia for oil-rich and Iran, Russia for gas-rich countries use nuclear energy for electric power production [10].

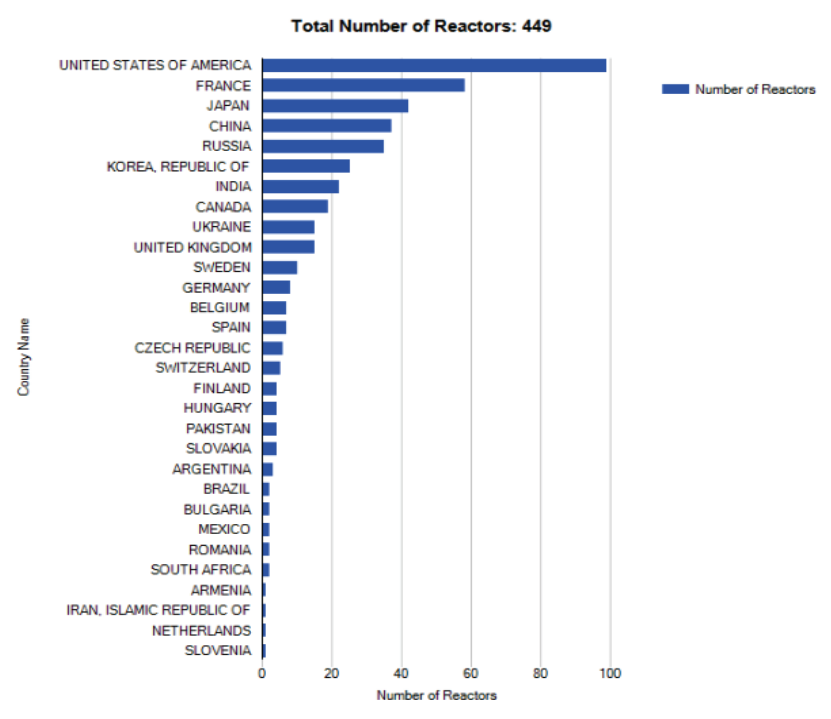

Fig. 1. Nuclear energy reactors for some countries [8]

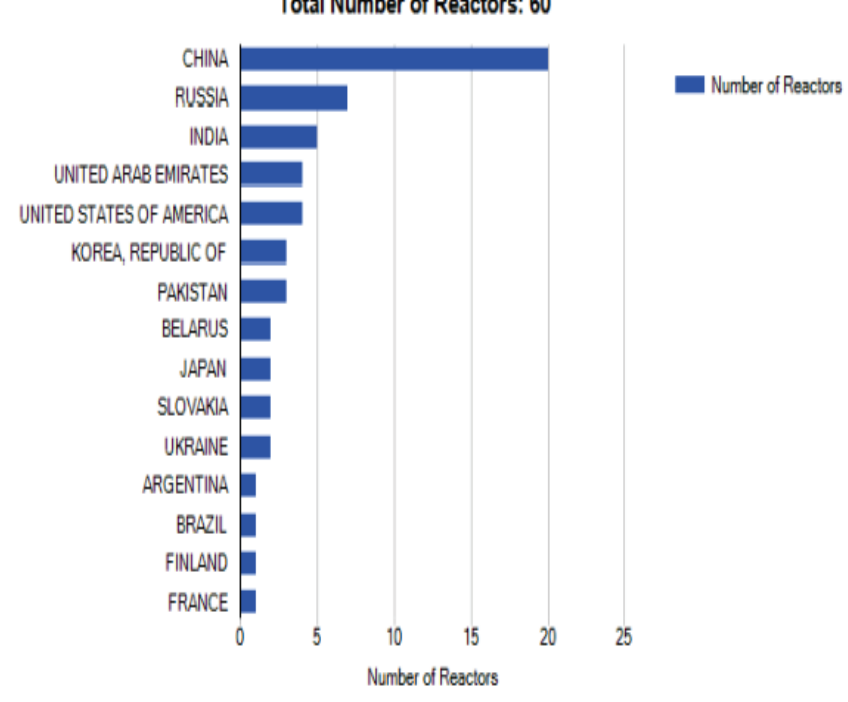

Fig. 2. Under construction reactors [8]

\subsection{Nuclear Power in the USA}

The USA is the world's largest producer of nuclear power, accounting for more than $30 \%$ of worldwide nuclear generation of electricity. The country's 100 nuclear reactors produced 805 billion $\mathrm{kWh}$ in 2016 , almost $20 \%$ of total electrical output. There are four reactors under construction. Following a 30-year period in which few new reactors were built, it is expected that four more new units will come online by 2021, these resulting from 16 license applications made since mid2007 to build 24 new nuclear reactors Government policy changes since the late 1990s have helped pave the way for significant growth in nuclear capacity [9].

\subsection{Nuclear Power in France}

France derives about $75 \%$ of its electricity from nuclear energy, due to a long-standing policy based on energy security. This share may be reduced to $50 \%$ by 2025 . France is the world's largest net exporter of electricity due to its very low cost of generation, and gains over $€ 3$ billion per year from this. France has been very active in developing nuclear technology. Reactors and especially fuel products and services have been a significant export. About $17 \%$ of France's electricity is from recycled nuclear fuel [9].

\subsection{Nuclear Power in the Russia}

Russia is moving steadily forward with plans for an expanded role of nuclear energy, including development of new reactor technology. An average of one large reactor per year is due to come on line to 2028, balancing retired capacity. Efficiency of nuclear generation in Russia has increased dramatically since the mid-1990s. Exports of nuclear goods and services are a major Russian policy and economic objective. Over 20 nuclear power reactors are confirmed or planned for export construction. Foreign orders totaled $\$ 133$ billion at the end of 2016 [9].

\subsection{Nuclear Power in the China}

Mainland China has 36 nuclear power reactors in operation, 21 under construction, and more about to start construction. Additional reactors are planned, including some of the world's most advanced, to give a doubling of nuclear capacity to at least 58 GWe by $2020-21$, then up to $150 \mathrm{GWe}$ by 2030 , and much more by 2050 . The impetus for increasing nuclear power share in China is increasingly due to air pollution from coal-fired plants. China's policy is to have a closed nuclear fuel cycle. China's policy is to 'go global' with exporting nuclear technology including heavy components in the supply chain [9].

\section{Nuclear Energy in the Turkey}

Turkey, which cannot meet its energy with local energy sources, has turned to nuclear energy as an alternative energy source. It is seen that conflicts and problems experienced in the geography in which Turkey is located impacts the energy security of Turkey and it is understood that this situation may have a negative influence on national security of Turkey. Because of all these reasons, actualizing nuclear energy projects are important for Turkey which is dependent in respect of energy [11]. Fig. 3 shows the plants planned to be installed in Turkey.

Turkey has had plans for establishing nuclear power generation since 1970.Today, plans for nuclear power are a key aspect of the country's aim for economic growth. Recent developments have seen Russia take a leading role in offering to finance and build $4800 \mathrm{MWe}$ of nuclear capacity. Application has been made for 
construction and operating licenses for the first plant, at Akkuyu, and construction start is expected in 2018.A Franco-Japanese consortium is to build the second nuclear plant, at Sinop. China is in line to build the third plant, with US-derived technology. A small uranium mining project is planned [9].

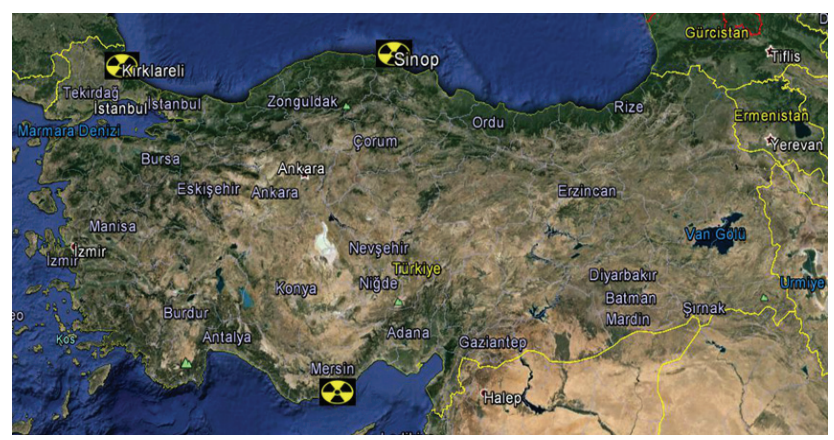

Fig. 3. The nuclear reactors are planned to be established in Turkey [12]

\subsection{Akkuyu NGS}

Turkish Electricity Trade \& Contract Corporation (TETAS) called for tenders in March 2008, inviting bids for the first nuclear power plant at Akkuyu, near the port of Mersin in Mersin province on the eastern Mediterranean coast. Turkish Atomic Energy Authority (TAEK) issued specifications, allowing for Pressurized Water Reactor (PWR), Boiling Water Reactor (BWR) or Pressurized Heavy Water Reactor (PHWR) types of at least $600 \mathrm{MWe}$ and with 40-year service life. Design certification in country of origin was acceptable, allowing TAEK to concentrate on site-specific aspects of the $4800 \mathrm{MWe}$ project. In the event, only one bid was received from 14 interested parties, this being from Atomstroyexport in conjunction with Inter RAO (both from Russia) and Park Teknik (Turkey), for an AES-2006 power plant with four $1200 \mathrm{MWe}$ reactors [13].

Following commercial advice from TETAS, a government decision was expected in April 2009, but in fact only a series of statements resulted, regarding the cost of power over the first 15 years being too high. Then in August 2009 two agreements between TAEK and Rosatom were signed with much fanfare. One was a nuclear cooperation agreement, the other was a standard one on the early notification on a nuclear accident and the exchange of information on nuclear facilities. These progressed the possibility of a Russian nuclear project at Akkuyu, probably with $25 \%$ government equity to dampen the likely electricity price rise. The first reactor was expected to come online in 2016, and others in 2017, 2018 and 2019. However, following a ruling by the country's top legal body, TETAS cancelled the Atomstroyexport agreement and said that a new tender would be launched soon. Instead, the parties proceeded to a direct high-level agreement.

Atomstroyexport is general contractor for construction. Early in 2017 the energy minister suggested 2017 start. In June 2016 Rosatom said that construction would start in 2018. In August 2016, the government said that it would classify the project as a strategic investment, allowing favorable tax treatment.

TAEK on 9 February 2017; Akkuyu approved the field parameters to be used in the design of the plant, which has been determined by Nuclear Inc. in detail and which has been justified and submitted to the approval of the Agency within the scope of the Akkuyu Nuclear Power Plant Field Parameters Report (SPR). The report prepared in line with the results of the engineering studies obtained on the nuclear power plant site to be established, contains the precise values acquired for reflection in Akkuyu NGS design Project [14].

\subsection{Sinop NGS}

Since February 2008 preparatory work has been under way at Sinop on the Black Sea coast to build a second nuclear plant there, along with a $€ 1.7$ billion nuclear technology centre. A 5000-5600 MWe nuclear plant there is expected to cost about $\$ 22-25$ billion.

A feasibility study is due for completion in mid-2017, and the announced timeline is for construction start in 2017 and operation from 2023. These are likely to be the first Atmea1 units built. They would be designed for load-following and use the same steam generators as Areva's large EPR (but three instead of four). Cost is projected at $\$ 4.89$ billion each. MHI has set up a new business unit, the Turkey Nuclear IPP Development Department, to handle the feasibility study, negotiate contracts, prepare financing and undertake other functions in Turkey. In April 2014, an intergovernmental agreement was signed with Japan for development of the plant. MHI will lead the engineering-procurementconstruction (EPC) consortium [9].

\subsection{Igneada}

There are plans to build further nuclear capacity at another site, as part of $100 \mathrm{GWe}$ required by 2030 . TAEK has identified Igneada in Kirklareli province on the Black Sea, $12 \mathrm{~km}$ from the Bulgarian border, and this was confirmed in October 2015. Akcakoca between it and Sinop was also considered. When agreement for the development of the Sinop plant was to have been finalized, the energy ministry was to announce the site for the third plant with an invitation for expressions of interest to be issued by the end of 2013. This didn't happen and in October 2014 the prime minister said that the project would be substantially indigenous, with construction start about 2019 [9].

\section{Expectations of energy future of Turkey}

Integration of nuclear energy into our energy supply sources will be one of the major means for decreasing the risks emerging from dependency to imported fuels by satisfying the increasing electric energy demand. MENR targets that the share of nuclear power plants in electric energy generation will reach at least $10 \%$ by the end of 2023. To achieve this target, it is planned that two nuclear power plants will be in operation and one will be under construction by the end of 2023 . 
According to the Agreement with the Japan, 4 units of ATMEA-1 type reactor, each with 1,120 MW power, will be constructed in Sinop province. Total installed capacity of Sinop NPP is 4480 MWe and total lifetime of each units is 60 years. It is expected that first two units of Sinop NPP will be in operation in 2023 and 2024 and other two units in 2027 and 2028. For third nuclear power plant, site selection studies are ongoing [15].

Tablo 1. Planned Nuclear Power Plants

\begin{tabular}{|l|l|l|l|}
\hline $\begin{array}{l}\text { Station/Project } \\
\text { Name }\end{array}$ & Type & $\begin{array}{l}\text { Capacity } \\
(\mathrm{MWe})\end{array}$ & \\
\hline Akkuyu NPP-1 & VVER-1200 & 1200 & $2016-2020$ \\
\hline Akkuyu NPP-2 & VVER-1200 & 1200 & $2017-2021$ \\
\hline Akkuyu NPP-3 & VVER-1200 & 1200 & $2018-2022$ \\
\hline Akkuyu NPP-4 & VVER-1200 & 1200 & $2019-2023$ \\
\hline Sinop NPP-1 & ATMEA-1 & 1120 & $2019-2023$ \\
\hline Sinop NPP-2 & ATMEA-2 & 1120 & $2020-2024$ \\
\hline Sinop NPP-3 & ATMEA-3 & 1120 & $2023-2027$ \\
\hline Sinop NPP-4 & ATMEA-4 & 1120 & $2024-2028$ \\
\hline
\end{tabular}

\section{Conclusion}

In Turkey and in the world, the current state of nuclear energy is generally evaluated using new data. The energy resources of the world are rapidly depleting, problems such as costs and global warming are increasing. In this context, nuclear energy studies should be supported, but studies should be carried out with great care to minimize accidents. It is an inevitable fact to put nuclear energy into operation so that Turkey can provide energy independence and energy supply security. Public awareness of nuclear waste should be raised. The wrong judgments on the nuclear issue must be resolved. Together with these developments, it is necessary to exploit alternative sources in Turkey and optimally utilize these resources.

\section{Acknowledgements}

The study is supported by Osmaniye Korkut Ata University through the projects OKUBAP-2016-PT3001 .

\section{References}

1. Yıldırım M.ve Örnek İ; Gaziantep Üniversitesi Sosyal Bilimler Dergisi 6(1):32-44 (2007)

2. Arto, I., Capellán-Pérez, I., Lago, R., Bueno, G., \& Bermejo, R. (2016). Energy for Sustainable Development, 33, pp: 1-13.

3. Bahçe, A.B., and Gümüş. Usak University Journal of Social Sciences, 9(2), 2016

4. Yildırım, M., \& Ornek, I. (2007). Gaziantep University Social Sciences,6(1), pp :32-44.

5. Council Regulation (EURATOM), 1999, No 2587/1999, (Article 41 of the Treaty establishing the European Atomic Energy Community, December 1999), s.2.

6. M. Toman, B. Jemelkova, Resources for the Future, Vol.41, (April 2003), s.1.

7. B. Colijn and B. Van Ark, "Growth in Six European Countries", Neujobs Deliverable, Vol.3 No.3. (2014), s.6.

8. https://www.iaea.org/PRIS/WorldStatistics/OperationalReactorsB yCountry.aspx
9. World Nuclear Assocation Nuclear Power http://www.worldnuclear.org/

10. http://www.enerji.gov.tr/

11. Furuncu, Y. (2016). Cumhuriyet Science Journal, 37, pp: 207-216.

12. Kaplan, Y.A., and C. Aladağ. EPJ Web of Conferences. Vol. 128. EDP Sciences, 2016.

13. Y1lmaz, E.A. Republican University Literature Faculty Social Sciences Journal , 39.1 (2015), pp:227-245.

14. http://www.akkunpp.com/

15. http://www-pub.iaea.org/ 